\title{
KRONIKA
}

KRYSTYNA HELAND-KURZAK

Wydział Nauk Pedagogicznych

Akademia Pedagogiki Specjalnej im. Marii Grzegorzewskiej

Warszawa

Forum Pedagogiczne $2017 / 2$

Wpłynęło: 28.04.2017 Zatwierdzono do druku: 12.05.2017 DOI: 10.21697/fp.2017.2.27

\section{Spotkanie Zespołu Pedagogiki Ogólnej KNP PAN (Warszawa, 21 kwietnia 2017 roku)}

Posiedzenie Zespołu Pedagogiki Ogólnej, działającego przy Komitecie Nauk Pedagogicznych Polskiej Akademii Nauk, miało miejsce 21 kwietnia 2017 roku w Uniwersytecie Kardynała Stefana Wyszyńskiego w Warszawie (UKSW). W spotkaniu uczestniczyli: Lucyna Dziaczkowska (KUL JP II), Jarosław Gara (APS), Michał Głażewski (UP), Rafał Godoń (UW), Krystyna Heland-Kurzak (APS), Monika Maciejewska (UW-M), Henryk Mizerek (UW-M), Mirosława NowakDziemianowicz (DSW), Justyna Nowotniak (US), Jan Piskurewicz (UKSW), Witold Starnawski (UKSW), Dariusz Stępkowski (UKSW), Marcin Wasilewski (UŁ), Rafał Włodarczyk (UWr), Alina Wróbel (UŁ), Edyta Zawadzka (APS), Witold Żłobicki (UWr) i Alicja Żywczok (UŚ). Obradom przewodniczył przewodniczący zespołu Roman Leppert (UKW). Przybyłych powitał Witold Starnawski, prodziekan Wydziału Pedagogicznego UKSW, który wyraził nadzieję, że spotkanie będzie okazją do dyskusji na wszystkie tematy, nie wyłączając tych trudnych.

Zgodnie z programem na początku wystąpił D. Stępkowski, który wygłosił referat pt. Pedagogika, która mówi nie. Nieafirmacyjna teoria pedagogiki ogólnej Dietricha Bennera. Prelegent wyjaśnił, że pierwsza część tytułu nawiązuje do książki Gastona Bachelarda pt. Filozofia, która mówi nie i celnie oddaje nastawienie badawcze analizowanego autora.

D. Stępkowski podzielił swoje rozważania na trzy części. Pierwszą zatytułował Zarys koncepcji teoriopoznawczej i poświęcił analizie trzech terminów: „nieafirmacyjny”, „refleksyjny” $i$ „,krytyczny”. Najpierw mówca poddał analizie językowej pojęcia „afirmatywny” i „afirmacyjny”. Oba pochodzą od łacińskiego rzeczownika affirmatio, który oznacza „zapewnienie”, „potwierdzenie”, i czasownika affirmare, który na język polski tłumaczy się jako „utwierdzać, wzmacniać”, „potwierdzać”, "zapewniać, zaręczać, utrzymywać, twierdzić". Na tym tle wyjaśnił, co należy rozumieć przez nieafirmacyjną pedagogikę ogólną. Jego zdaniem, jej sens dobrze opisuje wskazana powyżej triada terminów: „,nieafirmacyjny”, „refleksyjny” i „krytyczny”. Terminy nie tylko opisują nastawienie badawcze D. Bennera, lecz 
również stanowią swoisty klucz umożliwiający zrozumienie założeń myślenia pedagogicznego autora Pedagogiki ogólnej.

W drugiej części referent skupił się na węzłowych elementach struktury teoretycznej wspomnianego powyżej opracowania. Kategorią, którą wykorzystał w tym celu, była „złożoność”. Zdaniem D. Stępkowskiego, można dostrzec jej obecność w trzech zakresach problemowych, a mianowicie: 1) teoriopoznawczej konstrukcji obserwatora krytycznego; 2) koncepcji praxis pedagogicznej i 3) architektonice Pedagogiki ogólnej. Po tym w trzeciej części wystąpienia D. Stępkowski przybliżył stanowisko D. Bennera odnośnie do roli odgrywanej przez pedagogikę ogólną w badaniach pedagogicznych - tak teoretycznych, jak i empirycznych.

Po wystąpieniu odbyła się dyskusja, w której uczestnicy spotkania zwrócili uwagę m.in. na relację między teorią a praktyką pedagogiczną. Poza tym podjęto próbę odczytania terminu „złożoność” w odniesieniu do wychowania i kształcenia. Wskazywano, że „złożoność” może oznaczać zależności, związki i powiązania zarówno między wymienionymi dwoma obszarami działania pedagogicznego, jak i w ich wnętrzu. Odnośnie tego pierwszego D. Stępkowski przekonywał, że przez wychowanie należy rozumieć oddziaływania pedagogiczne celowe, „prowokujące” i „sztucznie” wywołane przez nauczyciela czy wychowawcę w celu wzbudzenia w uczniu czy wychowanku autonomicznego procesu (samo)kształcenia. Takie powiązanie tych dwóch elementów stanowi charakterystyczny rys Bennerowskiego myślenia ogólnopedagogicznego, w centrum którego usytuowana jest kategoria Bildung. Uczestnicy dyskusji podkreślali, że wskazane oddziaływania wychowawcze, które mają na celu pobudzenie podmiotu do własnej aktywności (samokształcenia), nie mogą ograniczać się wyłącznie do nauczania szkolnego. Nie ulega jednak wątpliwości, że szkoła ma być miejscem kształcenia, co z kolei oznacza poszukiwanie właściwych sposobów interwencji pedagogicznej.

Jednym $\mathrm{z}$ wątków dyskusji była kwestia sposobu interpretowania nieafirmacyjności. W kontekście pracy naukowej podkreślono, że uprawianie nauki wymaga od naukowca ciągłego i krytycznego sprawdzania tez i poglądów innych naukowców. W odniesieniu do wychowania moralnego potrzeba nieafirmacyjności ujawnia się przede wszystkim w potrzebie zdefiniowania własnego zadania działania pedagogicznego. Tylko dzięki temu wychowanie moralne może ustrzec się przed wykorzystaniem go jako narzędzia służącego obcym celom.

Na zakończenie dyskusji wyrażono przekonanie, że opracowanie Dietricha Bennera stanowi przemyślaną i syntetyczną konstrukcję teoretyczną, która czerpie z dorobku historycznego pedagogiki i warta jest przybliżenia w Polsce.

W drugiej części spotkania W. Żłobicki i R. Włodarczyk z Uniwersytetu Wrocławskiego przedstawili projekt ogólnopolskiej konferencji naukowej pt. „Polskie koncepcje pedagogiki ogólnej w ujęciu porównawczym”. W skład komitetu naukowego konferencji zamierzają oni powołać dotychczasowych przewodniczących ZPO: Romana Schulza, Teresę Hejnicką-Bezwińską, Krystynę Ablewicz i Romana Lepperta. Ten ostatni zaproponował rozszerzenie tego gremium 
o Witolda Żłobickiego, jako reprezentanta organizatorów. Konferencja odbędzie się w dniach 27-28 września 2017 roku.

Po prezentacji dyskutowano nad zaproponowanymi obszarami tematycznymi konferencji: 1) historyczne i współczesne koncepcje pedagogiki ogólnej; 2) polskie a/i obecne w innych obszarach językowych koncepcje pedagogiki ogólnej; 3) pedagogika ogólna w perspektywie kierunków i prądów współczesnej pedagogiki; 4) status pedagogiki ogólnej i relacje pomiędzy pedagogiką ogólną a subdyscyplinami pedagogicznymi; 5) związki pedagogiki ogólnej z innymi dyscyplinami pedagogicznymi; 6) diagnoza zmian warunków instytucjonalnych uprawiania pedagogiki ogólnej; 7) mechanizmy integracji i dyferencjacji pedagogiki ogólnej; 8) recepcja koncepcji pedagogiki ogólnej wśród pedagogów; 9) postrzeganie roli i znaczenia pedagogiki ogólnej przez studentów kierunków pedagogicznych; 10) pedagogika ogólna - nowe wyzwania. Uczestnicy spotkania podkreślili, że ważne jest zachowanie słowa „polskie” w tytule konferencji ze względu na dorobek polskich badaczy w zakresie pedagogiki ogólnej, który nie powinien ulec zapomnieniu.

W kolejnej części spotkania A. Wróbel zaprosiła do udziału w seminarium naukowym, 7 czerwca 2017 roku na Wydziale Nauk o Wychowaniu Uniwersytetu Łódzkiego. Jego problematyka dotyczyła kształcenia jako kategorii metafizycznej. Seminarium to zostało połączone ze spotkaniem Zespołu Teorii Wychowania. $\mathrm{W}$ ten sposób zainicjowano cykl spotkań noszących wspólny tytuł „Kształcenie jako kategoria metahumanistyczna". W części panelowej seminarium referaty wygłosili: Bogusław Śliwerski, Krzysztof Maliszewski i Dariusz Stępkowski.

Po tym zaproszeniu R. Leppert poprosił o zabranie głosu R. Włodarczyka, który zaprezentował swoją książkę pt. Ideologia, teoria, edukacja. Myśl Ericha Fromma jako inspiracja dla pedagogiki współczesnej. Mówca rozpoczął od cytatu pochodzącego ze wstępu: „Miarą społecznej roli pedagogiki i pedagogów jest jakość ich włączania się podstawowe problemy i spory szeroko rozumianej humanistyki, zdolność do recepcji idei humanistyki swego czasu oraz krytycznego ich oglądu w kontekście problemów edukacyjnych jednostki i społeczeństwa. Zasadniczą płaszczyzną sporu i problematyzacji w pedagogice jest więc zawsze człowiek, wizja świata i wizja człowieka w świecie”. W dalszej części R. Włodarczyk przedstawił główne obszary tematyczne poruszone w monografii, a mianowicie: 1) analiza kategorii ideologii w edukacji w teorii i praktyce edukacji prac Ericha Fromma; 2) zapomniany Erich Fromm w pedagogice, próba odzyskania myśli Ericha Fromma we współczesnej pedagogice krytycznej; 3) uniwersalna potrzeba religii - przeniesienie kategorii na grunt pedagogiczny; 4) inspiracje Ericha Fromma ze znanych mu ideologii politycznych; 5) krytyka kategorii ideologii politycznej w teorii i pedagogice krytycznej; 6) utopia jako element zwieńczający Fromma koncepcję rozwoju człowieka; 7) wątek emancypacyjny u Ericha Fromma.

W związku z zaprezentowaną monografią podkreślono ogrom pracy włożonej przez R. Włodarczyka w opracowanie tak złożonego zagadnienia. Zabierający głos docenili autora za trafny dobór elementów charakteryzujących myśl humanistyczną 
E. Fromma, przede wszystkim tych rzadko poruszanych w literaturze przedmiotu i związanych z profetyzmem mesjańskim i judaizmem. Poza tym zwrócono uwagę na inspirujące konkluzje, do których autor doprowadza czytelników. Jedną z nich jest pedagogika azylu, która przeciwstawia się „pedagogice getta”.

Spotkanie zakończył przewodniczący ZPO R. Leppert, który podziękował wszystkim za przybycie, a organizatorom za przygotowanie spotkania. Jednocześnie przypomniał, że następne spotkanie odbędzie się na wskazanej konferencji we Wrocławiu. 